\title{
Response of Mango to Micronutrients through Soil and Foliar Applications on Fruit Quality and Shelf Life
}

\author{
H. L. Kacha* ${ }^{*}$ H. C. Patel and D. R. Paradava \\ College of Horticulture, AAU, Anand, India \\ *Corresponding author
}

\begin{abstract}
A B S T R A C T
The experiment was conducted at the Horticultural Research Farm, Department of Horticulture, B. A. College of Agriculture, Anand Agricultural University, Anand during the spring and summer seasons of the year 2017-18 \& 2018-19 to study the "Response of mango to micronutrients through soil and foliar applications on fruit quality and shelf life". The experiment comprised of 13 treatments of different micronutrients application viz. ferrous sulphate $100 \mathrm{~g}$, zinc sulphate $100 \mathrm{~g}$, borax $100 \mathrm{~g}$ and multimicronutrients grade-V $400 \mathrm{~g}$ as a soil application; ferrous sulphate $0.5 \%$, zinc sulphate $0.5 \%$, borax $0.2 \%$ and multimicronutrients grade-IV $1.0 \%$ as a foliar application; soil application of ferrous sulphate $100 \mathrm{~g}$ followed by foliar application of ferrous sulphate $0.5 \%$, soil application of zinc sulphate $100 \mathrm{~g}$ followed by foliar application of zinc sulphate $0.5 \%$, soil application of borax $100 \mathrm{~g}$ followed by foliar application of borax $0.2 \%$ and soil application of multimicronutrients grade- $\mathrm{V} 400 \mathrm{~g}$ followed by foliar application of multimicronutrients grade-IV $1.0 \%$ and control (water spray). Soil application was done at second fortnight of September and foliar spray of treatments was done at flower bud initiation, full bloom stage and pea stage initiation on 18 years old mango cv. Mallika. Experiment was laid out in a Completely Randomized Design (CRD) with three repetitions. The higher total soluble solids (24.4 and $24.2{ }^{\circ} \mathrm{Brix}$ ), reducing sugar (10.6 and $10.5 \%$ ), non-reducing sugar (12.7 and $12.6 \%$ ), total sugar (23.2 and $23.0 \%$ ), ascorbic acid (28.7 and $27.4 \mathrm{mg} / 100 \mathrm{~g}$ pulp) and lower titrable acidity per cent $(0.21$ and $0.20 \%)$ as well as maximum shelf life of fruit (15.0 and 13.7 days) were recorded with treatment soil application of multimicronutrients grade- $\mathrm{V} 400 \mathrm{~g}$ followed by foliar application of multimicronutrients grade-IV $1.0 \%$ during both successive years.
\end{abstract}

Keywords

Mango, Quality, Shelf life

\section{Article Info}

Accepted:

17 October 2020 Available Online: 10 November 2020

\section{Introduction}

Mango (Mangifera indica L.) is a premier fruit crop of India considering its area, production, popularity among the people and designated as the 'National Fruit of India'. Mango, the King of fruits, is grown in India for over 4000 years. The mango is a fleshy stone fruit belonging to the genus Mangifera, consisting of numerous tropical fruiting trees that are cultivated mostly for edible fruits belonging to family Anarcardiacae. Mangifera indica - the common mango' is the only mango tree commonly cultivated in 
many tropical and subtropical regions. It originated in South East Asia. Mango is one of the major fruits of Asia and has developed its own importance all over the world. Being a useful and delicious fruit, it is the part of culture and religion since the time immemorial. Its taste, flavor and aroma are very fascinating to everyone. Because of these naturally built in qualities, mango is now gradually gaining global popularity during the last couple of years. It occupies relatively same position in tropical region as is enjoyed by apple in the temperate region. It is now being grown at least in 111 countries spread over five continents (Anon., 1992).

India shares about 56 per cent of total mango production in the World. Besides India, it is also being cultivated in Pakistan, Bangladesh, Burma, Sri Lanka, Thailand, Veitnam, Malasiya, Philippines, Indonesia, South Africa, USA, Venezuela and Brazil. In India, it is cultivated on an area of 2.26 million hectares with annual production of 21.82 million tonnes having productivity of 9.65 MT per hectare (Anon., 2018). Mango is almost grown in all states of India. The Andhra Pradesh is leading in total production, whereas, Uttar Pradesh is leading in area under mango cultivation. In Gujarat, it is cultivated on an area of 0.16 million hectares with production of 1.21 million tonnes with productivity of 7.56 MT per hectare (Anon., 2018). Mango trees perform well both under tropical and subtropical climatic conditions. Mango is having wider adaptability with respect to soil, climate and altitude for its successful cultivation. The trees can survive at 10 to $45{ }^{\circ} \mathrm{C}$ but the optimum range of temperature is 21 to $27{ }^{\circ} \mathrm{C}$. It requires good rainfall during its growing season (June to October) and rainless dry weather from November onwards. Mango having good nutritional value as every $100 \mathrm{~g}$ of mango fruit contains $81.7 \mathrm{~g}$ water, $16 \mathrm{~g}$ carbohydrate, $0.7 \mathrm{~g}$ protein, $0.4 \mathrm{~g}$ fat and $0.1 \mathrm{~g}$ fibers. It is rich in calcium, phosphorus, iron, magnesium, vitamin -A, B, C and also full of antioxidants. A single fruit can provide up to 40 $\%$ daily dietary fiber needs (Chandra and Chandra, 1997). Its fruit is large in size, oblong elliptical in shape and cadmium yellow in colour, fruit weight $400-500 \mathrm{~g}$, pulp 72-77\%, TSS $15-18{ }^{0}$ Brix, acidity 0.30-0.50 $\%$ and fiber content relatively lower. Fruit taste and keeping quality are good. It is a late season variety.

In mango, many problems are associated with fruit set, yield and quality due to imbalance supply of nutrients and it results in poor health of plants, fruit quality, increase in fruit drop and moreover the unhealthy plants are also more prone to attack of insect-pest and diseases. The reason for low productivity, fruit drops and undersized or inferior quality of fruit may be due to genetically, environmental and cultural practices including application of chemical fertilizers. Macronutrients as well as micronutrients are the key elements in plant, found equally important for the growth and development. Micronutrients play a vital role in various enzymatic activities and synthesis of assimilates and hormones. Their acute deficiencies some time poses the problem of incurable nature (Kumar, 2002). These micronutrients also help in the uptake of major nutrients and play an active role in the plant metabolism process starting from cell wall development to respiration, photosynthesis, chlorophyll formation, enzymatic activity, hormone synthesis, nitrogen fixation and reduction etc. (Das, 2003). Among the various micronutrients, zinc element is important for the formation and activity of chlorophyll and in the functioning of several enzymes. It is an important constituent of Triptophane, a precursor of growth hormone (auxin). It is also essential for the transformation of carbohydrates and regulates consumption of 
sugars. Kumar and Chakrabati (1992) noted that the higher sugar content and lower acidity percentage of fruits by the spray of $\mathrm{ZnSO}_{4} 1.0$ $\%$ in 30 year old mango orchard. Iron is necessary for many enzymatic functions and as a catalyst for the synthesis of chlorophyll, protein and regulates the respiration. It is essential for the development of young growing parts of the plant. It is very important constituent of ferredoxin. Boron element is much required for cell division and development in the growth regions of the plant near the tips of shoots and roots. It aids production of sugar and carbohydrates. It also affects sugar transport and appears to be associated with some of the functions of calcium. Boron affects pollination and development of viable seeds which in turn affect the normal development of fruit (Zia et al., 2006). It is also act as enhancing the pollen germination, pollen tube growth, sugar synthesis and sugar accumulation (Shaban, 2010). Boron deficiency also causes fruit cracking and distorted growth in plants. Application of boron has also resulted in improving fruit quality like fruit weight, TSS, total sugars and pulp colour (Pandey and Singh, 2007; Dutta, 2004 and Abd-Allah, 2006).

\section{Materials and Methods}

An experiment was conducted at Horticultural Research Farm, Department of Horticulture, B. A. College of Agriculture, Anand Agricultural University, Anand during spring - Summer season of the years 2017-18 and 2018-19. The soil of the experimental site was loamy sand. The soil is alluvial by their nature of origin, very deep, well drained and fairly moisture retentive. Soils respond well to manures and irrigations. The climate of Anand region is semi-arid and sub-tropical type. Winter is mild cool and dry, while summer is hot and dry and average annual rainfall is $830 \mathrm{~mm}$. The experiment comprised of 13 treatments of different micronutrients application viz. ferrous sulphate $100 \mathrm{~g}$, zinc sulphate $100 \mathrm{~g}$, borax $100 \mathrm{~g}$ and multimicronutrients grade- $\mathrm{V} 400 \mathrm{~g}$ as a soil application; ferrous sulphate $0.5 \%$, zinc sulphate $0.5 \%$, borax $0.2 \%$ and multimicronutrients grade-IV $1.0 \%$ as a foliar application; soil application of ferrous sulphate $100 \mathrm{~g}$ followed by foliar application of ferrous sulphate $0.5 \%$, soil application of zinc sulphate $100 \mathrm{~g}$ followed by foliar application of zinc sulphate $0.5 \%$, soil application of borax $100 \mathrm{~g}$ followed by foliar application of borax $0.2 \%$ and soil application of multimicronutrients grade- $\mathrm{V}$ $400 \mathrm{~g}$ followed by foliar application of multimicronutrients grade-IV $1.0 \%$ and control (water spray). Soil application was done at second fortnight of September and foliar sprays of treatments were done at flower bud initiation, full bloom stage and pea stage initiation on 18 years old mango cv. Mallika.

Experiment was laid out in a Completely Randomized Design (CRD) with three repetitions. Recommended dose of farm yard manure (100 kg/tree) and NPK fertilizers (750:160:750 g NPK/tree) were given as common dose in all the treatments and it's applied with band placement method. All other cultural operations including weeding and plant protection measures were carried as per the package of practices of mango. The mature and uniform sized fruits were harvested from the respective trees where observations were recorded regarding the quality parameters of the fruits. The experimental data collected relating to different parameters were statistically analyzed as described by Gomez and Gomez (1976). Treatment means of all characters for individual were compared by means of critical differences at $5 \%$ level of significance after employing ' $\mathrm{F}$ ' test. 


\section{Results and Discussion}

The data pertaining to quality parameters clearly indicate that the mango trees showed differential response towards soil and foliar application of micronutrients treatments.

\section{Total Soluble Solids $\left({ }^{\circ}\right.$ Brix $)$}

A close scrutiny of the data revealed that the treatment effects were significantly different in individual years (Table 1). In first year, total soluble solid $\left(24.4^{\circ}\right.$ Brix $)$ was obtained significantly maximum in mango fruit with treatment $\mathrm{T}_{12} \quad$ (soil application of multimicronutrients grade- $\mathrm{V} 400 \mathrm{~g}$ followed by foliar application of multimicronutrients grade-IV $1.0 \%$ ) however, it was at par with treatments $\mathrm{T}_{8}\left(23.9^{\circ} \mathrm{Brix}\right), \mathrm{T}_{11}\left(23.6^{\circ} \mathrm{Brix}\right)$, $\mathrm{T}_{7}\left(23.2{ }^{\circ}\right.$ Brix $), \mathrm{T}_{10}\left(23.2{ }^{\circ}\right.$ Brix $)$ and $\mathrm{T}_{9}(22.8$ ${ }^{\circ}$ Brix). While it was minimum (17.2 ${ }^{\circ}$ Brix $)$ recorded in control $\left(\mathrm{T}_{13}\right)$. However, in second year of the experimentation data exhibited same trend in respect to TSS.

Soil application of multimicronutrients grade-V $400 \mathrm{~g}$ followed by foliar application of multimicronutrients grade-IV $1.0 \%\left(\mathrm{~T}_{12}\right)$ was observed most effective treatment regarding TSS content $\left(24.2^{\circ}\right.$ Brix $)$ in mango fruit and it was at par with other treatment viz. $\mathrm{T}_{8}$ (foliar application of multimicronutrients grade-IV $1.0 \%$ ), $\mathrm{T}_{11}$ (soil application of borax $100 \mathrm{~g}$ followed by foliar application of borax $0.2 \%$ ), $\mathrm{T}_{7}$ (foliar application of borax $0.2 \%$ ) and $\mathrm{T}_{10}$ (soil application of $\mathrm{ZnSO}_{4} 100 \mathrm{~g}$ followed by foliar application of $\mathrm{ZnSO}_{4} 0.5$ $\%)$. However, the minimum TSS $\left(18.1^{\circ}\right.$ Brix $)$ was recorded with $\mathrm{T}_{13}$ (control) treatment. This might be due to the fact that zinc increases the synthesis of tryptophan that is a precursor of auxin. It plays a key role in protein synthesis, sugar metabolism and maintains the integral structure. On the other hand, boron may be associated with the cell membrane where it could be complex with sugar molecules and facilitates its passage across the membrane that might be the reason for increased Total Soluble Solids. This results are in conformity with the finding of Bhowmick and Banik (2011), Nehete et al., (2011), Bhatt et al., (2012), Bhowmick et al., (2012) in mango, Meena et al., (2006) in ber and Singh et al., (2001), Vishwakarma et al., (2008), Shukla et al., (2011) and Chandra and Singh (2015) in aonla.

\section{Titrable Acidity (\%)}

Significantly the lowest fruit acidity $(0.21$ and $0.20 \%$ ) was recorded in treatment $\mathrm{T}_{12}$ i.e. soil application of multimicronutrients grade- $\mathrm{V}$ $400 \mathrm{~g}$ followed by foliar application of multimicronutrients grade-IV $1.0 \%$ during both years of experimentation. The highest fruit acidity was recorded in control treatment $(0.35$ and $0.34 \%)$. This might be due to the fact that boron plays an important role in carbohydrate metabolism, translocation of sugar, starch and phosphorus, etc. While zinc influences activities of dehydrogenise enzyme e.g. glucose-6, phosphate which decrease the acidity.

On the other hands iron and Mn carries enzymatic activities and reduction in respiration and all these activities may help in reduction of acidity. Similar results have been reported by Balakrishnan (2001) who found lowest acidity percentage with combined foliar application $0.25 \% \mathrm{Zn}+0.25 \% \mathrm{Fe}+$ $0.25 \% \mathrm{Mn}+0.1 \% \mathrm{~B}$ in guava. The present study is partially supported with the findings of Bhowmick and Banik (2011), Nehete et al., (2011), Singh et al., (2013) in mango and Meena et al., (2006) in ber.

\section{Reducing Sugar (\%)}

Data (Table 2) exhibited for both the year of experiments (2017-18 and 2018-19), significantly maximum reducing sugar per 
cent (10.6 and $10.5 \%)$ was registered with treatment $\mathrm{T}_{12}$ (soil application of multimicronutrients grade- $\mathrm{V} 400 \mathrm{~g}$ followed by foliar application of multimicronutrients grade-IV $1.0 \%$ ) and it was statistically at par with treatments $\mathrm{T}_{8}$ (foliar application of multimicronutrients grade-IV $1.0 \%$ ) with value 10.1 and $10.4 \%$. However, control had found minimum reducing sugar per cent (6.6 and $6.7 \%$, respectively). The higher percentage of reducing sugar was recorded in the soil and foliar application of micronutrients.

An association of zinc with synthesis of auxin in plants played a vital role along with the increase in enzymatic activities. It also acts as a catalyst in oxidation-reduction processes in plants.

Mango possesses climacteric phenomenon which triggers into the dramatic changes in respiration. This leads the biochemical reactions including conversion of complex food material i.e. starch into simple substances like sugars. Fe is associated with the development of flavour proteins.

Besides, Zn helps in other enzymatic reactions like transformation of carbohydrates, activity of hexokinase and formation of cellulose and change in sugar are considered due to its action on zymohexose (Dutta and Dhua, 2002). These results are in close conformity with the findings of Anees et al., (2011), Nehete et al., (2011) and Bhatt et al., (2012) in mango and Jat and Kacha (2014) in guava.

\section{Non Reducing Sugar (\%)}

Data (Table 2) for both the successive years of study (2017-18 and 2018-19) accounted significantly maximum non reducing sugar per cent (12.7 and 12.6\%) was recorded with treatment $\mathrm{T}_{12}$ (soil application of multimicronutrients grade- $\mathrm{V} 400 \mathrm{~g}$ followed by foliar application of multimicronutrients grade-IV $1.0 \%$ ) which was at par with treatments viz. $\mathrm{T}_{8}$ i.e. foliar application of multimicronutrients grade-IV $1.0 \%, \mathrm{~T}_{11}$ i.e. soil application of borax $100 \mathrm{~g}$ followed by foliar application of borax $0.2 \%$ and $\mathrm{T}_{7}$ i.e. (foliar application of borax $0.2 \%$ ) while minimum non reducing sugar per cent $(9.0$ and $9.1 \%$ ) was noted under control.

\section{Total Sugar (\%)}

During the first year of study, significantly maximum total sugar $(23.2 \%)$ was obtained in mango fruit with treatment $\mathrm{T}_{12}$ (soil application of multimicronutrients grade- $\mathrm{V}$ $400 \mathrm{~g}$ followed by foliar application of multimicronutrients grade-IV $1.0 \%$ ) and it was found statistically at par with treatment $\mathrm{T}_{8}(22.3 \%)$.

The minimum total sugar per cent $(15.7 \%)$ was recorded in mango fruit with control. Further, in second year data of the experimentation same trend was observed with respect to total sugar per cent. Soil application of multimicronutrients grade- $\mathrm{V}$ $400 \mathrm{~g}$ followed by foliar application of multimicronutrients grade-IV $1.0 \%$ was found most effective regarding total sugar $(23.0 \%)$ content in mango fruit and remaining at par with treatment $\mathrm{T}_{8}$ i.e. foliar application of multimicronutrients grade-IV $1.0 \%(22.9 \%)$.

However, the minimum total sugar (15.7\%) was recorded with control. The improvement in total sugar content in fruit might be due to the catalytic action of micronutrients particularly at higher concentrations. Hence the foliar application of micronutrients quickly increased the uptake of macronutrients in the tissues and organs and improves fruit quality (Anees et al., 2011). 
Table.1 Effect of different application methods of micronutrients on total soluble solids and tritrable acidity

\begin{tabular}{|c|c|c|c|c|c|}
\hline \multirow[t]{2}{*}{$\begin{array}{l}\text { Treat. } \\
\text { No. }\end{array}$} & \multirow[t]{2}{*}{ Treatments details } & \multicolumn{2}{|c|}{$\begin{array}{l}\text { Total soluble solid } \\
\left.\text { ( }{ }^{\mathbf{C} B r i x}\right)\end{array}$} & \multicolumn{2}{|c|}{ Titrable Acidity (\%) } \\
\hline & & 2017-18 & 2018-19 & 2017-18 & 2018-19 \\
\hline $\mathbf{T}_{1}$ & Soil application of $\mathrm{FeSO}_{4} 100 \mathrm{~g}$ & 21.3 & 19.5 & 0.34 & 0.33 \\
\hline $\mathbf{T}_{2}$ & Soil application of $\mathrm{ZnSO}_{4} 100 \mathrm{~g}$ & 21.5 & 20.0 & 0.34 & 0.32 \\
\hline $\mathbf{T}_{3}$ & Soil application borax $100 \mathrm{~g}$ & 22.1 & 20.7 & 0.32 & 0.31 \\
\hline $\mathbf{T}_{4}$ & Soil application of multimicronutrients grade-V $400 \mathrm{~g}$ & 22.3 & 20.9 & 0.30 & 0.30 \\
\hline $\mathbf{T}_{5}$ & Foliar application of $\mathrm{FeSO}_{4} 0.5 \%$ & 22.4 & 21.2 & 0.31 & 0.30 \\
\hline $\mathbf{T}_{6}$ & Foliar application of $\mathrm{ZnSO}_{4} 0.5 \%$ & 22.7 & 21.4 & 0.31 & 0.29 \\
\hline $\mathbf{T}_{7}$ & Foliar application of borax $0.2 \%$ & 23.2 & 22.8 & 0.29 & 0.27 \\
\hline $\mathbf{T}_{8}$ & Foliar application of multimicronutrients grade-IV $1.0 \%$ & 23.9 & 23.7 & 0.25 & 0.23 \\
\hline $\mathbf{T}_{9}$ & Soil application of $\mathrm{FeSO}_{4} 100 \mathrm{~g}$ followed by foliar application of $\mathrm{FeSO}_{4} 0.5 \%$ & 22.8 & 21.7 & 0.27 & 0.28 \\
\hline $\mathbf{T}_{10}$ & Soil application of $\mathrm{ZnSO}_{4} 100 \mathrm{~g}$ followed by foliar application of $\mathrm{ZnSO}_{4} 0.5 \%$ & 23.2 & 22.7 & 0.28 & 0.28 \\
\hline $\mathbf{T}_{11}$ & Soil application of borax $100 \mathrm{~g}$ followed by foliar application of borax $0.2 \%$ & 23.6 & 23.3 & 0.27 & 0.25 \\
\hline $\mathbf{T}_{12}$ & $\begin{array}{l}\text { Soil application of multimicronutrients grade- } \mathrm{V} 400 \mathrm{~g} \text { followed by foliar } \\
\text { application of multimicronutrients grade-IV } 1.0 \%\end{array}$ & 24.4 & 24.2 & 0.21 & 0.20 \\
\hline $\mathbf{T}_{13}$ & Control & 17.2 & 18.1 & 0.35 & 0.34 \\
\hline & S.Em \pm & 0.59 & 0.62 & 0.01 & 0.01 \\
\hline & C. D. $(P=0.05)$ & 1.73 & 1.79 & 0.02 & 0.02 \\
\hline & C.V. \% & 4.60 & 4.95 & 4.99 & 5.06 \\
\hline
\end{tabular}


Table.2 Effect of different application methods of micronutrients on reducing, non reducing and total sugar

\begin{tabular}{|c|c|c|c|c|c|c|c|}
\hline \multirow[t]{2}{*}{$\begin{array}{l}\text { Treat. } \\
\text { No. }\end{array}$} & \multirow[t]{2}{*}{ Treatments details } & \multicolumn{2}{|c|}{ Reducing sugar $(\%)$} & \multicolumn{2}{|c|}{$\begin{array}{l}\text { Non reducing sugar } \\
\qquad(\%)\end{array}$} & \multicolumn{2}{|c|}{ Total sugar (\%) } \\
\hline & & 2017-18 & 2018-19 & 2017-18 & 2018-19 & 2017-18 & 2018-19 \\
\hline $\mathbf{T}_{1}$ & Soil application of $\mathrm{FeSO}_{4} 100 \mathrm{~g}$ & 7.3 & 7.5 & 9.9 & 10.2 & 17.2 & 17.7 \\
\hline $\mathbf{T}_{2}$ & Soil application of $\mathrm{ZnSO}_{4} 100 \mathrm{~g}$ & 7.9 & 7.8 & 10.8 & 10.6 & 18.7 & 18.5 \\
\hline $\mathbf{T}_{3}$ & Soil application borax $100 \mathrm{~g}$ & 8.4 & 7.7 & 11.5 & 10.5 & 19.9 & 18.2 \\
\hline $\mathbf{T}_{4}$ & Soil application of multimicronutrients grade-V $400 \mathrm{~g}$ & 8.5 & 8.0 & 11.6 & 10.8 & 20.1 & 18.8 \\
\hline $\mathbf{T}_{5}$ & Foliar application of $\mathrm{FeSO}_{4} 0.5 \%$ & 8.1 & 8.1 & 11.0 & 11.1 & 19.1 & 19.2 \\
\hline $\mathbf{T}_{6}$ & Foliar application of $\mathrm{ZnSO}_{4} 0.5 \%$ & 8.4 & 8.6 & 11.4 & 11.7 & 19.8 & 20.2 \\
\hline $\mathbf{T}_{7}$ & Foliar application of borax $0.2 \%$ & 8.9 & 9.1 & 11.8 & 12.0 & 20.7 & 21.1 \\
\hline $\mathbf{T}_{8}$ & Foliar application of multimicronutrients grade-IV $1.0 \%$ & 10.1 & 10.4 & 12.2 & 12.5 & 22.3 & 22.9 \\
\hline $\mathbf{T}_{9}$ & $\begin{array}{l}\text { Soil application of } \mathrm{FeSO}_{4} 100 \mathrm{~g} \text { followed by foliar application } \\
\text { of } \mathrm{FeSO}_{4} 0.5 \%\end{array}$ & 8.6 & 8.2 & 11.7 & 11.2 & 20.3 & 19.4 \\
\hline $\mathbf{T}_{10}$ & $\begin{array}{l}\text { Soil application of } \mathrm{ZnSO}_{4} 100 \mathrm{~g} \text { followed by foliar application } \\
\text { of } \mathrm{ZnSO}_{4} 0.5 \%\end{array}$ & 8.3 & 8.9 & 11.3 & 12.1 & 19.5 & 21.1 \\
\hline $\mathbf{T}_{11}$ & $\begin{array}{l}\text { Soil application of borax } 100 \mathrm{~g} \text { followed by foliar application } \\
\text { of borax } 0.2 \%\end{array}$ & 8.8 & 9.0 & 12.0 & 12.3 & 20.8 & 21.3 \\
\hline $\mathbf{T}_{12}$ & $\begin{array}{l}\text { Soil application of multimicronutrients grade-V } 400 \mathrm{~g} \\
\text { followed by foliar application of multimicronutrients grade-IV } \\
1.0 \%\end{array}$ & 10.6 & 10.5 & 12.7 & 12.6 & 23.2 & 23.0 \\
\hline $\mathbf{T}_{13}$ & Control & 6.6 & 6.7 & 9.0 & 9.1 & 15.7 & 15.7 \\
\hline & S.Em \pm & 0.24 & 0.25 & 0.32 & 0.32 & 0.57 & 0.57 \\
\hline & C. D. $(P=0.05)$ & 0.70 & 0.72 & 0.94 & 0.94 & 1.65 & 1.66 \\
\hline & C.V. $\%$ & 4.93 & 5.07 & 4.98 & 4.96 & 4.96 & 5.01 \\
\hline
\end{tabular}


Table.3 Effect of different application methods of micronutrients on ascorbic acid and shelf life of mango fruit

\begin{tabular}{|c|c|c|c|c|c|}
\hline \multirow[t]{2}{*}{$\begin{array}{l}\text { Treat. } \\
\text { No. }\end{array}$} & \multirow[t]{2}{*}{ Treatments details } & \multicolumn{2}{|c|}{$\begin{array}{l}\text { Ascorbic Acid } \\
\text { (mg/100g pulp) }\end{array}$} & \multicolumn{2}{|c|}{$\begin{array}{l}\text { Shelf life of fruits } \\
\text { (days) }\end{array}$} \\
\hline & & 2017-18 & 2018-19 & 2017-18 & 2018-19 \\
\hline $\mathbf{T}_{1}$ & Soil application of $\mathrm{FeSO}_{4} 100 \mathrm{~g}$ & 22.0 & 22.3 & 11.3 & 9.3 \\
\hline $\mathbf{T}_{2}$ & Soil application of $\mathrm{ZnSO}_{4} 100 \mathrm{~g}$ & 22.7 & 22.6 & 11.7 & 10.0 \\
\hline $\mathbf{T}_{3}$ & Soil application borax $100 \mathrm{~g}$ & 23.8 & 23.0 & 12.0 & 10.3 \\
\hline $\mathbf{T}_{4}$ & Soil application of multimicronutrients grade-V $400 \mathrm{~g}$ & 24.0 & 23.3 & 12.3 & 10.7 \\
\hline $\mathbf{T}_{5}$ & Foliar application of $\mathrm{FeSO}_{4} 0.5 \%$ & 23.2 & 22.9 & 12.0 & 11.0 \\
\hline $\mathbf{T}_{6}$ & Foliar application of $\mathrm{ZnSO}_{4} 0.5 \%$ & 24.2 & 23.0 & 12.3 & 11.3 \\
\hline $\mathbf{T}_{7}$ & Foliar application of borax $0.2 \%$ & 26.5 & 24.8 & 13.3 & 12.0 \\
\hline $\mathbf{T}_{8}$ & Foliar application of multimicronutrients grade-IV $1.0 \%$ & 27.7 & 26.6 & 14.3 & 12.7 \\
\hline $\mathbf{T}_{9}$ & Soil application of $\mathrm{FeSO}_{4} 100 \mathrm{~g}$ followed by foliar application of $\mathrm{FeSO}_{4} 0.5 \%$ & 26.3 & 24.2 & 12.7 & 11.3 \\
\hline $\mathbf{T}_{10}$ & Soil application of $\mathrm{ZnSO}_{4} 100 \mathrm{~g}$ followed by foliar application of $\mathrm{ZnSO}_{4} 0.5 \%$ & 26.5 & 24.3 & 13.0 & 11.7 \\
\hline $\mathbf{T}_{11}$ & Soil application of borax $100 \mathrm{~g}$ followed by foliar application of borax $0.2 \%$ & 27.4 & 25.2 & 13.7 & 12.3 \\
\hline $\mathbf{T}_{12}$ & $\begin{array}{l}\text { Soil application of multimicronutrients grade- } \mathrm{V} 400 \mathrm{~g} \text { followed by foliar } \\
\text { application of multimicronutrients grade-IV } 1.0 \%\end{array}$ & 28.7 & 27.4 & 15.0 & 13.7 \\
\hline $\mathbf{T}_{13}$ & Control & 20.3 & 20.5 & 10.7 & 9.0 \\
\hline & S.Em \pm & 0.50 & 0.57 & 0.43 & 0.38 \\
\hline & C. D. $(P=0.05)$ & 1.46 & 1.66 & 1.25 & 1.12 \\
\hline & C.V. \% & 3.49 & 4.14 & 5.91 & 5.95 \\
\hline
\end{tabular}


The increase in total sugar can be attributed to the accumulation of oligosaccharides and polysaccharides in higher amount of zinc sulphate and boric acid while reduction in acid content may be based on the fact that mineral compounds reduced the acidity in fruits, since it is neutralized in plants during metabolic pathways and used in respiratory process as a substrate (Gowsami et al., 2014), Iron is also necessary for vital plant metabolic function such as chlorophyll synthesis, various enzymatic reaction, respiration and photosynthesis so that the main product of photosynthesis is sugar, so increasing the photosynthesis, lead to increase the sugar compounds in fruit juice (Ram and Bose, 2000). Thus, the total sugar was improved by boron, iron, magnesium, manganese, zinc and copper. The findings of present study are in accordance with those of Bhowmick and Banik (2011), Nehete et al., (2011), Bhatt et al., (2012) and Anees et al., (2011) in mango, Kundu and Mitra (1999), Balakrishanan (2001), Pal et al., (2008), Rawat et al., (2010), Trivedi et al., (2012), Kumawat et al., (2012), Waskela et al., (2013), Rajkumar and Shant (2014), Jat and Kacha (2014) and Goswami et al., (2014) in guava.

\section{Ascorbic Acid (mg/100g pulp)}

A close examination of data (Table 3) evidenced that treatments used had significant influence on improving the content of ascorbic acid in fruits during both the years of experimentation. Significantly maximum ascorbic acid (28.7 mg/100g pulp) was noted with treatment $\mathrm{T}_{12}$ (soil application of multimicronutrients grade- $\mathrm{V} 400 \mathrm{~g}$ followed by foliar application of multimicronutrients grade-IV $1.0 \%$ ) which was statistically at par with treatments $\mathrm{T}_{8}$ (foliar application of multimicronutrients grade-IV $1.0 \%$ ) and $\mathrm{T}_{11}$ (soil application of borax $100 \mathrm{~g}$ followed by foliar application of borax $0.2 \%$ ). Minimum ascorbic acid (20.3 mg/100g pulp) was estimated under control $\mathrm{T}_{13}$ (control) during the year 2017-18. The trend of different micronutrient treatment was almost similar in the second year (2018-19). Soil application of multimicronutrients grade- $\mathrm{V} 400 \mathrm{~g}$ followed by foliar application of multimicronutrients grade-IV $1.0 \%\left(\mathrm{~T}_{12}\right)$ was found superior over rest of the treatments of micronutrients in respect to ascorbic acid content in mango fruit. The maximum ascorbic acid content in fruit was recorded with application of micronutrient it might be due to catalytic activity of zinc, iron and boron on its biosynthesis from its precursor (glucose-6phosphate) or inhibition of its conversion into dehydro ascorbic acid by enzyme, ascorbic acid oxidation or both. The higher level of sugars in boron treated fruit along with foliar application of macronutrients, which increased the content of ascorbic acid, since ascorbic acid is synthesized from sugar (Singh et al., 2013) in mango. Similar results are also accordance with the findings of Bhowmick and Banik (2011), Nehete et al., (2011), Bhatt et al., (2012) in mango and Singh et al., (2001), Shukla et al., (2009), Vishwakarma et al., (2013), Chandra and Singh (2015) and Verma et al., (2016) in aonla.

\section{Shelf Life (Days)}

In first year of experiment, significantly higher (15.0 days) shelf life of mango fruit was obtained during storage period with treatment $\mathrm{T}_{12}$ (soil application of multimicronutrients grade- $\mathrm{V} 400 \mathrm{~g}$ followed by foliar application of multimicronutrients grade-IV $1.0 \%$ ) and it was statistically at par with treatments $\mathrm{T}_{8}$ (foliar application of multimicronutrients grade-IV $1.0 \%$ ) with numerical data 14.3 days and $T_{11}$ (soil application of borax $100 \mathrm{~g}$ followed by foliar application of borax $0.2 \%$ ) with numerical data 13.7 days while lower shelf life (10.7 days) was reported in control $\left(\mathrm{T}_{13}\right)$. However, 
in second year of the experimentation (Table 3 ), soil application of multimicronutrients grade-V $400 \mathrm{~g}$ followed by foliar application of multimicronutrients grade-IV $1.0 \%\left(\mathrm{~T}_{12}\right)$ was found most effective treatment regarding shelf life (13.7 days) of mango fruit and remaining at par with treatment $\mathrm{T}_{8}$ (foliar application of multimicronutrients grade-IV $1.0 \%$ ) with value 12.7 days of shelf life. However, the lowest shelf life (9.0 days) was recorded with control $\left(\mathrm{T}_{13}\right)$. This might be due to increased in concentration of boron of middle lamella of cell wall which provide physical strength to cell wall and improved fruit colour development and appearance. These findings are in accordance with the findings of Bhatt et al., (2012) and Singh et al., (2012) in mango.

From the two years of field study, it can be concluded that soil application of multimicronutrients grade- $\mathrm{V} 400 \mathrm{~g}$ followed by foliar applications of multimicronutrients grade-IV $1.0 \%$ at flower bud initiation, full bloom stage and pea stage initiation effectively found to good fruit quality and enhancing shelf life of mango cv. Mallika.

\section{References}

Abd-Allah, A. S. E. (2006). Effect of spraying some macro and micro nutrients on fruit set, yield and fruit quality of Washington Navel trees. Journal of Applied Sciences Research, 2 (11): 1059-1063.

Anees, M., Tahir, F. M., Shazad, J. and Mahmood, N. (2011). Effect of foliar application of micronutrients on quality of Mango (Mangifera indica L.) Dasehari fruit. Mycopathology, 9 (1): 25-28.

Anonymous (2018). District wise area and production. Department of Horticulture, Gujarat State.

Balakrishnan, K. (2001). Foliar spray of zinc, iron, boron and magnesium on vegetative growth, yield and quality of guava. Annals Plant Physiology, 14 (2): 151-153.

Bhatt, A. Mishra., N. K. Mishra, D. S. and Singh,
C. P. (2012). Foliar application of potassium, calcium, zinc and boron enhanced yield, quality and shelf life of mango. HortFlora Research Spectrum, 1 (4): 300-305.

Bhowmick, N., Banic, B. C., Hasan, M. A. and Ghosh, B. (2012). Response of pre-harvest foliar application of zinc and boron on mango cv. Amrapali under new alluvial zone of West Bengal. Indian Journal of Horticulture, 69 (3): 428-431.

Bhowmick, N. and Banik, B. C. (2011). Influence of pre-harvest foliar application of growth regulators and micronutrients on mango cv. Himsagar. Indian Journal of Horticulture, 68 (1): 103-107.

Chandra, A. and Chandra, A. (1997). Production and Postharvest Technology of Fruits. NBS publication and Distributors, Bikaner, India.

Chandra, R. and Singh., K. K. (2015). Foliar application of zinc sulphate, magnesium sulphate and copper sulphate on the yield and quality of aonla (Emblica officinallis Gaerth L.) cv. NA-7 under Garhwal Himalaya. Journal of Medicinal Plant Studies, 3 (5): 42-45.

Dutta, P. (2004). Effect of foliar boron application on panicle growth, fruit retention and physio-chemical characters of mango cv. Himsagar. Indian Journal of Horticulture, 61 (3): 265-266.

Goswami, A. K. Shukla., H. S. and Mishra, D. S. (2014). Influence of pre-harvest nutrients application on the physico-chemical quality and storage behaviour of guava (Psidium guajava L.) fruit cv. L-49. Progressive Horticulture, 46 (1): 54-57.

Jat, G. and Kacha, H. L. (2014). Response of guava to foliar application of urea andzinc on fruit set, yield and quality. Journal of AgriSearch, 1 (2): 86-91.

Kumawat, K. L., Sarolia, D. K. and Shukla, A. K. (2012) Growth, yield and quality of rejuvenated guava as influenced by thinning-bending and micronutrients. Indian Journal of Horticulture, 69 (4): 478483.

Kundu, S. and Mitra, S. K. (1999). Response of guava to foliar spray of copper, boron and zinc. Indian Agriculturist, 43 (1-2): 49-54.

Meena, V. S.; Yadav, P. K. and Bhati, B. S. 
(2006). Effect of ferrous sulphate and borax on fruit quality of ber. Progressive Horticulture, 38(2): 283-285.

Nehete, D. S. Padhiar, B. V. Shah, N. I., Bhalerao, P. P., Kolambe, B. N. and Bhalerao, R. R. (2011). Influence of micronutrient spray on flowering, yield, quality and nutrient content in leaf of mango cv. Kesar. Asian Journal of Horticulture, 6 (1): 63-67.

Pal, A., Pathak, R. K., Pal, K. and Singh, T. (2008): Effect of foliar application of nutrients on yield and quality of guava fruits (Psidium guajava L.) cv. Sardar guava. Progressive Horticulture, 3: 89-90.

Pandey, R. and Singh, C. P. (2007). Effect of preharvest foliar spray of micronutrients on chemical properties of mango fruit cv. Langra. Pantnagar Journal of Research, 5: 56-61.

Rajkumar, T.\& Shant, L. (2014). Effect of foliar application of zinc and boron on fruit yield and quality of winter season guava (Psidium guajava L.) cv. Pant Prabhat. Annals of Agriculture and Bio Research, 19 (1): 105-108.

Ram, R. A. and Bose, T. K. (2000). Effect of foliar application of mangnesium and micronutrients on growth, yield and fruit quality of mandarin orange. Indian Journal of Horticulture, 57 (3): 215-220.

Rawat, V, Tomar. Y. K. and Rawat, J. M. S. (2010). Influence of foliar application of micronutrients on the fruit quality of guava cv. Lucknow-49. Journal of Hill Agriculture, 1 (1): 63-66.

Shaban, M. M. (2010). Role of boron in plant nutrition and human health. American Journal of Plant Physiology, 5: 224-240.

Shukla, H. S., Kumar, V. and Tripathi, V. K. (2011). Effect of gibberellic acid and boron on development and quality of aonla fruits
'Banarasi'. Acta Horticulture, 890: 375380.

Singh, A. K., Singh, C. P. and Chauhan, P. (2012). Effect of pre-harvest chemical treatments and mulching on quality and marketability of Dashehari mango. Indian Journal of Horticulture, 69 (4): 462-466.

Singh, A. K., Singh, C. P., Lal, S. and Chauhan, P. (2013). Effect of micronutrients and sorbitol on fruit set, yield and quality of mango cv. Dashehari. Progressive Horticulture, 45 (1): 43-48.

Singh, H. K., Srivastava, A. K., Dwivedi, R., and Kumar, P. (2001). Effect of foliar feeding of micronutrients on plant growth, fruit quality, yield and internal fruit necrosis of aonla (Emblica officinalis Gaertn.) cv. Francis. Progressive Horticulture, 33 (1): 80-83.

Trivedi, N., Singh, D., Bahadur, V., Prasad, V. M. and Collis, J. P. (2012). Effect of foliar application of zinc and boron on yield and fruit quality of guava (Psidium guajava L.). HortFlora Research Spectrum, 1 (3): 281283.

Vishwakarma, G. A. L. Yadav. H. K. Singh and Jagveer Singh. (2013). Effect of foliar feeding of calcium and boron on yield and quality of aonla cv. NA-6. Plant archives, 13 (2): 1135-1138.

Waskela, R. S., Kanpure, R. N., Kumawat, B. R. and Kachouli, B. K. (2013). Effect of foliar spray of micronutrients on growth, yield and quality of guava (Psidium guajava L.) $\mathrm{cv}$. Dharidar. International Journal of Agricultural Sciences, 9 (2): 551-556.

Zia, M. H., Ahmad, R., Khaliq, I., Ahmad, A. and Irshad, M. (2006). Micronutrients status and management in orchards soils: applied aspects. Soil and Environment, 25 (1): 6-16.

\section{How to cite this article:}

Kacha, H. L., H. C. Patel and Paradava, D. R. 2020. Response of Mango to Micronutrients through Soil and Foliar Applications on Fruit Quality and Shelf Life. Int.J.Curr.Microbiol.App.Sci. 9(11): 2316-2326. doi: https://doi.org/10.20546/ijcmas.2020.911.278 